Indonesian Journal of Islamic Psychology

Volume 2. Number 2, December 2020 (p-ISSN: 2685-1482 e-ISSN 2714-7576)

website: http://e-journal.iainsalatiga.ac.id/index.php/ijip/index

\title{
Dukungan Sosial Dengan Fear of Failure Pada Foodpreneur
}

\author{
Yugi Murdafasmi1 ${ }^{*}$, Risana Rachmatan ${ }^{2}$, Haiyun Nisa $^{3}$, Irin Riamanda ${ }^{4}$ \\ 1234Program Studi Psikologi Fakultas Kedokteran Universitas Syiah Kuala, \\ Indonesia
}

\begin{abstract}
Social support is an exchange of resources between two individuals that are felt by both the giver and the recipient with the aim of improving the welfare of the recipient. The social support received by entrepreneurs will certainly affect the smooth running of the business being run. One of the biggest fears that are owned by entrepreneurs, especially foodpreneurs, is fear of failure. The research objective was to determine the relationship between social support and fear of failure in foodpreneurs. The measuring instruments used in this study were the Multidimensional Scale of Perceived Social Support $(\alpha=0.81)$ and The Performance Failure Appraisal Inventory ( $\alpha=0.87)$. The sample was obtained by using quota sampling technique with the criteria of entrepreneurs in the culinary field aged 18-34 years, having their own culinary business with a total sample of 342 people. The analysis results showed that there was a negative relationship between social support and fear of failure in foodpreneurs. So the higher the social support, the lower the fear of failure. Likewise, on the other hand, the lower the social support, the higher the fear of failure.
\end{abstract}

Keywords: Social support; fear of failure; foodpreneur

\begin{abstract}
Abstrak
Dukungan sosial merupakan pertukaran sumber daya antara dua individu yang dirasakan oleh pemberi maupun penerima dengan tujuan meningkatkan kesejahteraan bagi penerima. Dukungan sosial yang diterima oleh para pengusaha tentunya akan memengaruhi kelancaran dari usaha yang dijalankan. Salah satu ketakutan terbesar yang dimiliki oleh pengusaha terutama foodpreneur yaitu ketakutan akan kegagalan atau fear of failure. Tujuan penelitian adalah untuk mengetahui hubungan antara dukungan sosial dengan fear of failure pada foodpreneur. Alat ukur yang digunakan penelitian ini adalah Multidimensional Scale Of Perceived Social Support $(\alpha=0,81)$ dan The Performance Failure Appraisal Inventory $(\alpha=0,87)$. Perolehan sampel dilakukan dengan teknik quota sampling dengan kriteria pengusaha dalam bidang kuliner yang berumur 18-34 tahun, memiliki usaha kuliner sendiri dengan total sampel sebanyak 342 orang. Hasil analisa menunjukkan ada hubungan negatif antara dukungan sosial dengan fear of failure pada foodpreneur. Jadi semakin tinggi dukungan sosial maka semakin rendah fear of failure. Begitu juga sebaliknya bahwa semakin rendah dukungan sosial maka semakin tinggi fear offailure.
\end{abstract}

Kata Kunci: dukungan sosial; fear offailure; foodpreneur

* Corresponding Author

yugimurda1996@gmail.com 
Yugi Murdafasmi, Risana Rachmatan, Haiyun Nisa, Irin Riamanda

Pendahuluan

Pengusaha merupakan orang-orang yang memiliki kemampuan menganalisa peluang bisnis untuk mendapatkan keuntungan serta pengambilan keputusan atau tindakan yang tepat untuk menggapai kesuksesan (Nagel, 2016). Pengusaha adalah seseorang yang dapat mengatur, menciptakan peluang baru dengan mengenali sumber daya yang tersedia serta mendukung dan siap menghadapi risiko atau ketidakpastian (Zimmerer, 2001). pengusaha terbagi dalam lima jenis yang pertama yaitu womenpreneur, sociopreneur, ecopreneur, technopreneur dan foodpreneur (Emerhub, 2019). Foodpreneur merupakan istilah bagi pengusaha yang bergerak dalam bidang kuliner atau makanan (Emerhub, 2019).

Pengamat ekonomi digital Yudi Candra menyatakan bahwa dari 1500-1700 usaha yang dikelola pengusaha di Indonesia hanya 1\% yang sukses, sedangkan 99\% gagal (Winosa, 2019). Hal ini juga disampaikan oleh Menteri Komunikasi dan Informatika (Kemenkominfo) Rudiantara yang menyebutkan hanya $5 \%$ dari usaha yang bisa bertahan sedangkan 95\% mengalami kegagalan (Chua, 2019). Menjadi pengusaha memiliki peluang untuk gagal, kegagalan tersebut terjadi karena kurang mampu dalam melihat peluang usaha (Saiman, 2014).

Penyebabnya banyak pengusaha yang tidak memberikan solusisolusi yang inovatif untuk memenuhi kebutuhan masyarakat, banyak pengusaha yang hanya ikut-ikutan mendirikan perusahaan yang sama dengan perusahaan lain yang sudah sukses (Winosa, 2019). Faktor penyebab kegagalan pada pengusaha muda yang pertama adalah tidak menyediakan kebutuhan pasar dengan kisaran 42\%, kehabisan modal $29 \%$, tidak menemukan tim yang tepat 23\%, tersingkir dari kompetisi 19\% dan ketidaksesuaian harga 18\% dan penyebab lainnya juga bukan 
Yugi Murdafasmi, Risana Rachmatan, Haiyun Nisa, Irin Riamanda $\overline{\text { produk yang mudah digunakan, model bisnis yang tidak sempurna, tidak }}$ mementingkan marketing, kurang feedback dari konsumen dan terlalu dini untuk pasar dan banyak pengusaha yang hanya ikut-ikutan mendirikan usaha bisnis yang sama dengan usaha bisnis lain yang sudah sukses (Bhaskara, 2016). Factor-faktor tersebut yaitu fear of failure (Shia, 1998). Fear of failure merupakan sebuah bentuk dukungan untuk menghindari kegagalan terutama konsekuensi negatif berupa hilangnya pengaruh sosial, rasa malu dan merasa kerugian Atkinson (dalam Conroy, Kaye, \& Fifer, 2002).

Individu yang memiliki fear of failure cenderung menghindari keadaan yang memiliki risiko dan hal yang kompetitif dan tidak memiliki harapan untuk berhasil (Conroy, 2007). Kiswanto (2017) menyatakan karakteristik fear of failure pada pengusaha yakni takut akan hal kehabisan uang, serta takut akan berdampak terhadap karir mereka kelak. Dampak lain dari fear of failure yaitu timbulnya rasa malu yang dialami, penghargaan terhadap diri sendiri yang rendah, tidak percaya diri dan hilangnya dukungan hingga kebangkrutan atau kehilangan uang.

Dukungan sosial adalah bentuk kenyamanan psikologis dan fisik yang didapatkan individu dari teman maupun keluarga (Baron \& Byrne, 2000). Lebih lanjut, Toding, David dan Pali (2015) menyebutkan dukungan sosial merupakan rasa nyaman dari segi emosional dan psikis yang diterima dari keluarga, teman dan orang-orang yang berarti bagi individu. Septiawati (2017) mengungkapkan bahwa pengaruh dukungan sosial terhadap pengusaha sangatlah penting, terutama jika dukungan tersebut berasal dari orang yang memiliki hubungan sosial yang baik dengan orang yang menerima dukungan, bentuk dukungan tersebut dapat berupa informasi, tingkah laku maupun materi yang dapat memberikan individu merasa diperhatikan, disayangi dan bernilai. 
Yugi Murdafasmi, Risana Rachmatan, Haiyun Nisa, Irin Riamanda

$\overline{\text { Faktor pendukung seseorang untuk berwirausaha salah satunya adalah }}$ the parental regufee (Titik, 2006).

The parental regufee yaitu individu yang memiliki keluarga dengan latar belakang sebagai wirausaha yang menjadikan individu mendapatkan pengalaman maupun pembelajaran bisnis yang dikelola keluarganya (Titik, 2006). Selain itu, keluarga yang bukan dari wirausaha juga dapat berpengaruh dalam memberikan dukungan sosial untuk individu untuk membangun usaha (Masykur, 2017).

\section{Dukungan Sosial}

Dukungan sosial merupakan dukungan emosional dan bantuan material yang diterima dari orang lain, dukungan sosial dapat membantu individu mendapatkan kepercayaan dalam kemampuan dalam menangani stress (Brannon \& Feist, 2009). Dukungan sosial adalah kenyamanan, penghargaan, bantuan maupun perhatian yang didapatkan oleh individu dari individu lainnya, baik perorangan maupun kelompok (Sarafino, 1998).

Taylor (2009) menyatakan dukungan sosial sebagai bentuk kehadiran individu lain yang memperhatikan, menghormati, mencintai maupun menghargai dan menjadi bagian dalam hubungan komunikasi. Selanjutanya, Zimmet, Dahlem \& Farley (1988) mendefinisikan dukungan sosial merupakan dukungan yang diberikan oleh orang terdekat individu seperti dukungan keluarga, dukungan teman dan dukungan dari orang yang berarti bagi individu. Hal senada dikemukakan oleh Shumaker \& Browell (dalam Zimmet, 1988) menyatakan bahwa dukungan sosial merupakan pertukaran sumber daya antara dua individu yang di rasakan oleh pemberi maupun penerima dengan tujuan meningkatkan kesejahteraan bagi penerima. 
Yugi Murdafasmi, Risana Rachmatan, Haiyun Nisa, Irin Riamanda

Zimet, Dahlem dan Farley (1988) menggambarkan dukungan sosial dalam tiga bentuk yaitu:

a. Family support (Dukungan keluarga)

Dukungan ataupun bantuan yang di berikan oleh keluarga untuk individu seperti bantuan dalam membuat keputusan dan kebutuhan secara emosional.

b. Friend support (Dukungan teman)

Dukungan ataupun bantuan yang diberikan oleh teman-teman dalam membantu rutinitas sehari-hari maupun dalam bentuk bantuan lain.

c. Significant other support (Dukungan orang yang berarti)

Dukungan ataupun bantuan yang di berikan dari orang yang berarti dalam kehidupan individu, berupa rasa nyaman dan perasaan dihargai.

Fear Of Failure

Fear of failure merupakan motif untuk menghindari kegagalan dalam situasi penilaian dalam mencapai prestasi dan berkaitan dengan mengantisipasi rasa malu sebagai konsekuensi dari kegagalan (Atkinson, 1957). Jackaway dan Teevan (1976), mengungkapkan bahwa kecenderungan untuk menghindari kegagalan atau mencapai keberhasilan dalam situasi pencapaian merupakan hasil dari karakteristik kepribadian yang dinamakan dengan motif. Individu dengan tingkat fear of failure yang tinggi cenderung mengalami tingkat rasa malu yang lebih besar ketika gagal dan akan menurunkan kualitas diri dari kegagalan yang dialami tersebut (McGregor \& Elliot, 2005). McGregor dan Elliot (2005) juga menyatakan bahwa, fear of failure berakar dari hubungan antara orangtua dan anak.

Model multidimensional fear of failure oleh Conroy, Willow, dan Metzler (2002) dikembangkan dari teori emosi kognitif-motivasi- 
Yugi Murdafasmi, Risana Rachmatan, Haiyun Nisa, Irin Riamanda relasional oleh Lazarus. Teori kognitif-motivasi-relasional menyatakan emosi berkaitan dengan penilaian relasional-motivasi-kognitif yang mendefinisikan bagaimana perubahan yang dirasakan dalam hubungan individu dengan lingkungan mempengaruhi kemampuan individu untuk mencapai tujuan (Lazarus, 1991; Conroy, Poczwardowski, \& Henschen, 2001). Maknanya, ketika individu merasakan perubahan yang berkaitan dengan kegagalan maupun kesuksesan, individu harus menilai bagaimana perubahan tersebut memengaruhi kemampuan untuk mencapai tujuan sebelum mengalami emosi. Hal yang ditentukan pertama kali dalam penilaian tersebut adalah apakah tujuan individu dipengaruhi oleh perubahan timbal balik yang dirasakan, yang kedua tujuan yang mana yang terkena dampak, dan yang terakhir seberapa penting makna mencapai tujuan tersebut bagi individu (Conroy, Poczwardowski, \& Henschen, 2001).

Fear of failure dapat terjadi pada individu dikarenakan adanya rasa ketidakberfungsian sebagai objek sosial ketika gagal, sehingga individu yang gagal menjadi terisolasi secara sosial (Birney, Burdick, \& Teevan, 1969; (Conroy, Willow, dan Metzler, 2002). Berdasarkan pandangan teori relasional-motivasi-kognitif, kegagalan menjadi suatu ancaman bagi individu dikarenakan telah dihubungkan dengan konsekuensi yang tidak menyenangkan,

Selanjutnya diketahui bahwa fear of failure merupakan bentuk penghindaran yang disebabkan oleh emosi yang negatif dari dalam diri individu untuk mengantisipasi kemungkinan gagal yang akan menimbulkan rasa malu, turunnya konsep diri, serta pengaruh sosial dan yang berkaitan dengan ketidakmampuan dalam usaha untuk mencapai keberhasilan (Conroy, Willow, \& Metzler, 2002). 
Yugi Murdafasmi, Risana Rachmatan, Haiyun Nisa, Irin Riamanda

Elliot \& Trash, (2004) mendefinisikan fear of failure adalah sebuah bentuk penghindaran yang didasarkan pada pencapaian prestasi maupun keberhasilan. Sedangkan menurut Hardiansyah (2011) fear of failure adalah interprestasi negatif seseorang terhadap suatu situasi, interprestasi negatif tersebut berupa kayakinan irasional yang muncul akibat beberapa akibat seperti tuntutan dari orang lain.

Conroy, Willow, dan Metzler (2002) membagi konsekuensi dalam kegagalan yang telah dihubungkan dengan tingkat fear of failure dibagi menjadi 5 (lima) dimensi, yakni:

a. Ketakutan akan penghinaan dan rasa malu

Menjadi satu-satunya keyakinan yang dapat memperkirakan tujuan dari pencapaian karena menurunnya keyakinan akan kemampuan mereka untuk mengembangkan perencaan menjadi tujuan. Ketakutan akan penghinaan dan rasa malu menjadikan individu mencemaskan yang dipikirkan oleh orang lain tentang dirinya terkait rasa malu dan penghinaan yang akan didapatkan.

b. Ketakutan akan penurunan harga diri individu

Ketakutan ini menghasilkan rasa ketidakmampuan dalam diri individu. Individu akan merasa tidak cukup pintar, tidak cukup berbakat, tidak cukup berkompeten sehingga tidak dapat mengontrol kinerjanya dengan baik. Ketakutan ini akan mengakibatkan penurunan keterlibatan individu dalam suatu kegiatan.

c. Ketakutan akan ketidakpastian masa depan

Ketakutan ini berkaitan dengan tingkat motivasi intrinsik yang tinggi dan tingkat motivasi yang rendah. Ketidakpastian masa depan menimbulkan rasa takut pada individu karena dikhawatirkan akan 
Yugi Murdafasmi, Risana Rachmatan, Haiyun Nisa, Irin Riamanda merubah rencana yang telah dipersiapkan dan mempengaruhi masa depan individu.

d. Ketakutan akan hilangnya pengaruh sosial

Individu akan memperlakukan dirinya dengan sikap penolakan berlebihan ketika gagal. Individu merasa penilaian dari orang lain terhadap dirinya akan menurun ketika ia mengalami kegagalan, yang akan berakibat buruk bagi dirinya misalnya kehilangan rasa kepedulian dari orang terdekat, adanya ketakutan dijauhi orang lain dan tidak diberikan pertolongan oleh orang lain.

e. Ketakutan akan mengecewakan orang yang penting baginya

Ketakutan akan mengecewakan dan mendapat kritik dari orangorang yang penting dalam hidup individu dan pada ketakutan ini individu kurang menguatkan dirinya sendiri ketika gagal.

Menurut (Conroy 2002) ada beberapa faktor yang dapat memengaruhi fear of failure, yaitu:

a. Penilaian seseorang mengenai perubahan dilingkungannya, yaitu ketika individu menilai terhadap perubahan yang terjadi dilingkungannya memiliki kesesuaian dan relevan dengan tujuan yang telah direncanakan sebelumnya.

b. Pengaruh perubahan terhadap tujuan, yaitu menentukan apakah perubahan akan memengaruhi tujuan yang akan dicapai secara positif dan menguntungkan atau akan memberikan dampak negatif untuk meraih kesuksesan.

c. Mengenali tujuan secara spesifik, yaitu merencanakan tujuan lebih awal dan dilakukan secara rinci untuk menghindari terjadinya kegagalan. 
Yugi Murdafasmi, Risana Rachmatan, Haiyun Nisa, Irin Riamanda Foodpreneur

Foodpreneur merupakan istilah bagi para pemuda yang bergerak dalam bidang kuliner atau makanan, mulai berjualan dari pintu ke pintu sampai mendirikan kafe di berbagai lokasi yang strategis. Kuliner yang disajikan juga beragam. Foodpreneur adalah individu yang rajin menciptakan peluang bisnis mereka sendiri disektor industri jasa kuliner dengan inovasi-inovasi baru dalam pengembangan (Buciyasi, 2016).

\section{Metodologi penelitian}

Penelitian ini menggunakan pendekatan kuantitatif dengan metode penelitian korelasi. Penelitian melibatkan 342 sampel dengan karakteristik yaitu; Menjalankan usaha milik sendiri, Berdomisili di Aceh, Berusia 18 - 34 tahun dan Jenis usaha berupa kuliner. Skala yang digunakan untuk mengukur dukungan sosial pada penelitian ini adalah skala Multidimensional Scale Of Perceived Social Support (MSPSS) yang disusun oleh Zimet, Canty dan Mitchell (2000) untuk mengukur dukungan sosial yang didapatkan pada diri individu. Kemudian, skala yang juga digunakan untuk melihat fear of failure subjek pada penelitian ini adalah Performance Failure Appraisal Inventory (PFAI) yang disusun oleh Conroy (2007).

Penelitian diawali dengan menyiapkan alat ukur, melakukan expert review, melakukan pengujian skala (try out), mengajukan protokol etik penelitian kepada Komite Etik Penelitian Kesehatan (KEPK) Fakultas Kedokteran Universitas Syiah Kuala-RSUDZA, dan melakukan pengumpulan data penelitian menggunakan internet survey (google form). 
Yugi Murdafasmi, Risana Rachmatan, Haiyun Nisa, Irin Riamanda Hasil dan pembahasan

Penelitian ini bertujuan untuk mengetahui hubungan untuk mengetahui apakah terdapat hubungan antara dukungan sosial dengan fear of failure pada foodpreneur. dengan total sebanyak 342 subjek. Adapun data demografi yang diperoleh dari penelitian ini dapat dilihat pada tabel berikut:

Tabel 1.

Data Sosiodemografi Subjek Penelitian

\begin{tabular}{lccc}
\hline Kategori Usia & 160 & 47,11 & \\
18-23 tahun & 156 & 45,38 & 342 \\
24-29 tahun & 26 & 7,51 & \\
30-34 tahun & & & \\
& 177 & 51,4 & \\
Jenis Kelamin & 165 & 48,6 \\
Laki-laki & & & \\
Perempuan & & 36,41 \\
Domisili & 123 & 6,65 \\
Banda Aceh & 23 & 24,27 \\
Aceh Besar & 84 & 3,76 \\
Pidie \& Pidie jaya & 13 & 7,51 \\
Bireun & 26 & 7,51 \\
Lhokseumawe \& Aceh Utara & 26 & 5,79 \\
Langsa & 20 & 4,05 \\
Aceh Tengah \& Bener Meriah & 14 & \\
Aceh Jaya, Nagan Raya, Aceh & & 4,05 \\
barat & 13 & \\
Aceh Selatan, Abdya \& Aceh Sigkil & & \\
\hline
\end{tabular}

Hasil uji normalitas yang menggunakan teknik statistik one-sample kolmogorov-smirnov test menunjukkan bahwa kedua variabel tidak 
Yugi Murdafasmi, Risana Rachmatan, Haiyun Nisa, Irin Riamanda $\overline{\text { berdistribusi normal. Hal ini dapat dilihat dari nilai signifikansi (2-tailed) }}$ yang diperoleh lebih kecil dari 0,05 yaitu $(p)=0,000$. Hasil uji linearitas menunjukkan bahwa kedua variabel bersifat linear, setelah dilakukan uji linearitas melalui ANOVA test for linearity memiliki nilai (p) $=0,000$ $(\mathrm{p}<0,05)$. Kemudian, R squared dalam penelitian ini bernilai 0,70 artinya adalah variabel dukungan sosial memiliki pengaruh sebesar $7 \%$ terhadap variabel fear of failure.

Pada penelitian ini, uji hipotesis dilakukan dengan menggunakan analisis statistik non parametrik dengan teknik korelasi Pearson Product Moment karena terpenuhinya uji asumsi. Metode ini digunakan untuk menganalisa hubungan dukungan sosial dengan fear of failure pada foodpreneur. Hasil uji hipotesis menunjukkan bahwa nilai signifikansi pada penelitian ini dikatakan signifikan karena memiliki nilai yang lebih kecil dari 0,05 yaitu $(\mathrm{p})=0,000$ dan dengan nilai koefisiensi korelasi $(\mathrm{r})=-$ 0,264, hal ini menunjukkan bahwa terdapat hubungan negatif dan signifikan antara dukungan sosial dengan fear of failure pada foodpreneur. Koefisien korelasi negatif diartikan bahwa jika salah satu variabel memiliki skor yang tinggi, maka salah satu variabel lainnya akan rendah. Pada penelitian ini dapat disimpulkan bahwa semakin tinggi dukungan sosial pada subjek penelitian, maka akan semakin rendah fear of failure. Begitu juga sebaliknya, semakin rendah dukungan sosial pada subjek penelitian, maka fear of failure akan tinggi. Dengan demikian, hipotesis pada penelitian ini diterima karena terdapat hubungan dan nilai signifikansi yang lebih kecil dari 0,05. Kategorisasi terkait dukungan sosial dan fear of failure dapat dilihat pada tabel berikut:

Tabel 2.

Hasil Kategorisasi Dukungan Sosial 
Yugi Murdafasmi, Risana Rachmatan, Haiyun Nisa, Irin Riamanda

\begin{tabular}{cccc}
$\begin{array}{c}\text { Rumus Kategorisasi } \\
\text { Jenjang }\end{array}$ & Kategorisasi & Jumlah & Persentase \\
\hline $\mathrm{X}<36$ & Rendah & 11 & 3,2 \\
$36 \leq \mathrm{X}<60$ & Sedang & 120 & 35,1 \\
$X \geq 60$ & Tinggi & 211 & 61,7 \\
\hline Total & & 342 & 100 \\
\hline
\end{tabular}

Berdasarkan table 2, diketahui bahwa dari 342 subjek, terdapat 11 subjek $(3,2 \%)$ berada pada kategori dukungan sosial yang rendah, 120 subjek (35,1\%) berada pada kategori dukungan sosial sedang dan 211 subjek $(61,7 \%)$ berada pada kategori dukungan sosial tinggi.

Tabel 3.

Kategorisasi Fear of Failure

\begin{tabular}{cccc}
\hline $\begin{array}{c}\text { Rumus Kategorisasi } \\
\text { Jenjang }\end{array}$ & Kategorisasi & Jumlah & Persentase \\
\hline $\mathrm{X}<58$ & Rendah & 149 & 43,6 \\
$58 \leq \mathrm{X}<92$ & Sedang & 159 & 46,5 \\
$\mathrm{X} \geq 92$ & Tinggi & 34 & 9,9 \\
\hline Total & & 342 & 100 \\
\hline
\end{tabular}

Berdasarkan tabel 3, diketahui bahwa dari 342 subjek, terdapat 149 subjek $(43,6 \%)$ berada pada kategori Fear of Failure yang rendah, 159 subjek (46,5\%) berada pada kategori Fear of Failure sedang dan 34 subjek $(9,9 \%)$ berada pada kategori Fear of Failure tinggi.

Hasil analisis dalam penelitian ini didapatkan bahwa nilai signifikansi $(\mathrm{p})=0,000(\mathrm{p}<0,05)$. Hal ini menunjukkan bahwa terdapat hubungan dukungan sosial dengan fear of failure pada foodpreneur. Berdasarkan hasil data empiris kedua variabel dalam penelitian ini 
Yugi Murdafasmi, Risana Rachmatan, Haiyun Nisa, Irin Riamanda menunjukkan adanya keterikatan dua variabel dengan besaran nilai koefisien korelasi $(r)=-0,264$. Hasil ini menunjukkan adanya hubungan negatif antara dukungan sosial dengan fear of failure pada foodpreneur. Hal tersebut dapat dimaknai sebagai semakin tinggi dukungan sosial individu maka semakin rendah fear of failure, begitu pula sebaliknya semakin rendah dukungan sosial individu maka semakin tinggi pula fear of failure.

Penelitian ini menitikberatkan pada pengusaha dalam bidang kuliner atau foodpreneur karena foodpreneur sering mengalami fear of failure. Faktor yang membuat foodpreneur mengalami fear of failure yaitu karena yang pertama adalah manajemen keuangan yang buruk, banyak dari foodpreneur ini tidak menguasai tentang masalah keuangan, yang mana keuangan merupakan jantung utama suatu bisnis. Kedua yaitu foodpreneur lemah dalam mengontrol operasional, lemahnya kontrol operasional berdampak besar untuk mutu produk dan efisiensi biaya. Ketiga yaitu foodpreneur kurang paham dalam mengatasi persaingan dengan kompetitor, walaupun bisnis yang dijalankan outstanding dibandingkan kompetitor lain, tapi seorang foodpreneur harus tetap mengantisipasi karena bisa saja banyak kompetitor bermunculan dengan inovasi yang lebih baik dan unik terlebih lagi dengan semakin menjamurnya jenis bisnis kuliner yang beraneka ragam. Keempat yaitu foodpreneur tidak konsisten dalam menjaga mutu dan pelayanan yang berkualitas karena mutu tidak hanya dinilai dari indera pengecapan tapi juga dinilai dari segi porsi, bahan baku dan keamanannya. Begitu juga pelayanannya, bisnis kuliner dituntut harus memberi pelayanan yang terbaik untuk konsumen (Solihin, 2019).

Berdasarkan pengelompokkan kategorisasi dukungan sosial pada foodpreneur dalam penelitian ini dapat dilihat bahwa mayoritas 
Yugi Murdafasmi, Risana Rachmatan, Haiyun Nisa, Irin Riamanda

foodpreneur memiliki dukungan sosial pada tingkatan kategori tinggi. Hal ini terlihat dari hasil kategorisasi dukungan sosial, yaitu sebanyak 211 subjek (61,7\%) berada kategori tinggi, 120 subjek $(35,1 \%)$ dan yang termasuk kategori sedang dan sebanyak 11 subjek $(3,2 \%)$ termasuk dalam kategori rendah. Temuan ini memberikan gambaran bahwa tinggi rendahnya dukungan sosial dipengaruhi oleh beberapa faktor, diantaranya adanya pemberi atau penyedia dan penerima dukungan serta komposisi dan struktur jaringan sosial, faktor-faktor tersebut sangat erat kaitannya dengan bentuk dukungan sosial yang diterima individu (Gardner, dalam Sarafino \& Smith, 2010). Sarason, Levine, Basham (1983) menjelaskan bahwa individu yang mendapatkan dukungan sosial tinggi artinya adalah individu tersebut mendapatkan dukungan sosial baik dari segi kualitas dan dari segi kuantitas (banyaknya orang disekitarnya yang mendukung) yang berarti tingkat kepuasan yang dirasakan oleh individu dari orang-orang sekitar didapatkan secara maksimal. Hal senada diungkapkan oleh Sarason \& Pierce (1987) yang menjelaskan tingginya dukungan sosial menandakan bahwa individu merasa senang dikarenakan orang-orang terdekatnya selalu ada setiap dibutuhkan sehingga membuat individu tersebut puas akan bentuk-bentuk dukungan yang didapatkan dari orang-orang sekitarnya. Hal ini didukung penelitian yang dilakukan Maulida (2012) menemukan bahwa dukungan sosial yang tinggi dapat memotivasi untuk menjalankan usaha. Selanjutnya penelitian yang dilakukan oleh Ekasari (2014) menemukan bahwa dukungan sosial memengaruhi secara signifikan terhadap motivasi ketika berwirausaha. Kemudian, penelitian Safitri, Suharso dan Ani (2015) menyatakan bahwa keadaan sosial yang baik bagi foodpreneur saat menjalankan bisnis akan membuat individu bersemangat dan tidak ragu dan takut dalam menjalankan bisnisnya. 
Yugi Murdafasmi, Risana Rachmatan, Haiyun Nisa, Irin Riamanda $\overline{\text { Penelitian yang dilakukan oleh Septiawati (2017) mengenai dukungan }}$ sosial bagi foodpreneur menemukan bahwa terdapat pengaruh yang menunjukkan dukungan sosial yang tinggi maka akan menyebabkan minat dalam menjalankan bisnis semakin meningkat. Karena dalam menjalankan bisnis diperlukan dukungan sosial seperti dukungan dari orang tua maupun lingkungan karena tanpa adanya dukungan maka minat dalam menjalankan usaha tidak akan tumbuh.

Lebih lanjut, Sulistiawan (2016) menyebutkan bahwa dukungan sosial yang terdiri dari dukungan sosial dari keluarga, teman, pemerintah, dana finansial, memiliki dampak positif yang signifikan terhadap kepercayaan dan mengurangi rasa ragu maupun takut. Hal ini mengindikasikan bahwa dukungan yang dirasakan oleh seseorang akan membuatnya semakin percaya diri mengenai kemampuannya dalam menjalankan suatu usaha, sesuai dengan penelitian yang dilakukan oleh Byabashaija dan Katono (2011) yang menyatakan bahwa dukungan yang dirasakan oleh foodpreneur akan meningkatkan self-efficacy atau kepercayaan diri untuk menjalankan bisnisnya. Kemudian dapat diketahui pula bahwa self-efficacy berpengaruh positif signifikan terhadap niat untuk berwirausaha. Semakin tinggi tingkat kepercayaan diri pada foodpreneur mengenai kemampuannya untuk mengelola dan menjalankan suatu usaha maka semakin tinggi pula niat untuk berwirausaha.

Hasil penelitian ini didukung dengan hasil penelitian sebelumnya yang menyatakan bahwa self-efficacy merupakan predictor penting dalam membangun rasa semangat untuk menjalankan usaha, salah satu faktor yang dapat menghambat semangat untuk menjalankan usaha yaitu perasaan Fear of Failure. Hal ini sesuai dengan penelitian yang dilakukan oleh Shinnar, dkk (2012) bahwa tingginya tingkat 
Yugi Murdafasmi, Risana Rachmatan, Haiyun Nisa, Irin Riamanda

penghindaran dan kurang rasa percaya diri terhadap risiko akan membuat seseorang untuk takut mengambil risiko dan cenderung mengalami rasa takut akan kegagalan. Conroy, Kaye, \& Fifer, (2002) yang menyebutkan bahwa fear of failure merupakan sebuah bentuk dukungan untuk menghindari kegagalan terutama konsekuensi negatif yaitu berupa hilangnya pengaruh sosial, perasaan malu dan merasa takut akan kerugian.

Berdasarkan pengelompokkan kategorisasi fear of failure pada foodpreneur dapat dilihat bahwa mayoritas foodpreneur memiliki fear of failure pada subjek berada pada tingkatan sedang. Hal ini terlihat dari hasil kategorisasi fear of failure, yaitu sebanyak 159 subjek (46,5\%) berada pada kategori sedang, 149 subjek (43,6\%) berada pada kategori Fear of Failure yang rendah dan 34 subjek (9,9\%) berada pada kategori Fear of Failure tinggi. Temuan ini memberikan gambaran bahwa tinggi rendahnya tingkat fear of failure dapat dipengaruhi oleh beberapa faktor diantaranya adalah penilaian seseorang mengenai perubahan lingkungannya, pengaruh perubahan terhadap tujuan dan mengenali tujuan secara spesifik. Faktor-faktor tersebut sangat erat kaitannya dengan bentuk fear of failure yang memengaruhi individu (Conroy, 2002). Atkinson (dalam Sagar \& Stoeber, 2009) menjelaskan bahwa semakin individu mengalami fear of failure maka akan semakin lemah usaha yang dilakukan agar bisa terhindar dari kegagalan. Begitu juga sebaliknya semakin individu tidak takut akan kegagalan maka semakin kuat usaha yang dilakukan agar terhindar dari kegagalan. Hal senada juga diungkapkan Poerwadaminta (dalam Chandrawati, 2009) yang menyatakan apabila individu dalam melakukan suatu usaha dengan direncanakan lebih awal dan dilakukan secara rinci maka akan dapat menghindari terjadinya fear of failure. Elliot \& Sheldon (1997) juga 
Yugi Murdafasmi, Risana Rachmatan, Haiyun Nisa, Irin Riamanda menambahkan tinggi rendahnya individu yang mengalami fear of failure akan mengakibatkan kurangnya minat individu dalam usaha melakukan pekerjaan dan tidak maksimalnya performa individu dalam berusaha.

Hal tersebut juga diperkuat dengan penelitian yang dilakukan Poewadaminat (dalam Chandrawati, 2009) yang mengatakan bahwa ketika fear of failure pada pengusaha meningkat maka kecendrungan semangat pengusaha tersebut menurun. Selanjutnya diperkuat juga oleh penelitian yang dilakukan Fadhillah (2015) yang mengatakan bahwa ketika fear of failure yang meningkat maka akan mempengaruhi intensi pengusaha untuk menjalankan usahanya.

Lebih lanjut, berdasarkan analisa pengelompokkan kategori dari aspek dukungan sosial dapat dilihat bahwa foodpreneur mendapatkan dukungan lebih besar dari keluarga sebesar 33,8\%, kemudian foodpreneur mendapatkan dukungan dari teman sebesar 33,4\% dan dukungan yang didapatkan dari significant other sebesar 32,8\%. Hal ini memberikan gambaran bahwa pada penelitian ini foodpreneur lebih tinggi mendapatkan dukungan dari keluarga.

Kemudian berdasarkan hasil analisa kategori fear of failure berdasarkan aspek-aspek dapat dilihat bahwa aspek yang memengaruhi fear of failure pada foodpreneur dalam penelitian ini adalah aspek akan ketakutan mengalami penghinaan dan rasa malu dengan besaran $27,9 \%$ hal ini menunjukkan bahwa foodpreneur dalam penelitian ini memiliki keresahan akan rasa malu apabila mengalami kegagalan. Hal tersebut didukung oleh Kiswanto (2017) yang menyatakan bahwa salah satu penyebab timbulnya fear of failure yaitu dampak psikologi berupa perasaan malu serta takut akan kehilangan dukungan. Terlihat juga bahwa salah satu aspek dukungan sosial yang memberikan semangat 
Yugi Murdafasmi, Risana Rachmatan, Haiyun Nisa, Irin Riamanda

serta membantu menumbuhkan kepercayaan diri yaitu dukungan dari keluarga (Kuncoro, 2002).

Penelitian Storey \& Greene (2010) mengatakan bahwa pengusaha yang berusia rentang 18-34 tahun cenderung mengalami fear of failure karena tidak mendapatkan akses modal, oleh karenanya pengusaha yang akan terkendala secara sumber daya, keuangan dan dukungan sosial yang dapat menyebabkan bisnisnya cenderung akan gagal, hal ini dikarenakan bahwa pada usia muda tersebut masih menguji dan mengambil kesempatan dalam pemilihan karir dan bisa saja melakukan perubahan karir. Sesuai dengan penelitian ini, sebanyak 342 subjek sebagai foodpreneur dengan rentang usia 18-34 tahun, hal ini terlihat dari persentase sampel terbesar mayoritas berada pada kategori usia 1823 tahun sebanyak 160 subjek (47,11\%), 24-29 tahun sebanyak 156 subjek $(45,38 \%)$ dan persentase terkecil berada pada kategori usia 3034 tahun sebanyak 26 subjek (7,51\%). Green (2013) menyebutkan bahwa foodpreneur yang berusia muda biasanya belum memiliki sumber daya manusia, keuangan dan sosial yang diperlukan untuk mendirikan bisnis maupun menjalankan bisnis dibandingkan dengan individu yang lebih tua dikarenakan foodpreneur dengan usia muda ini masih minim akan pengalaman bisnis selain itu bisnis yang dijalankan secara individu berpotensi mengalami kegagalan.

Penelitian ini juga memperoleh angka koefisien determinasi $(R$ squared) yaitu 0,70 atau sama dengan 7,0 \%. Hal ini mengandung arti bahwa variabel dukungan sosial memengaruhi variabel fear of failure sebesar 7,0\%. Sedangkan sisanya 93\% dipengaruhi oleh faktor intensi berwirausaha dan minat berwirausaha. Hal ini selaras dengan penelitian yang dilakukan oleh Fadhillah (2015) yang mana pada penelitian tersebut menghasilkan bahwa faktor intensi berwirausaha menjadi 
Yugi Murdafasmi, Risana Rachmatan, Haiyun Nisa, Irin Riamanda penyebabnya timbul perasaan fear of failure. Kemudian faktor yang memengaruhi fear of failure yaitu faktor minat berwirausaha seperi penelitian yang dilakukan oleh Wibawa (2014) hasil penelitian tersebut menyatakan bahwa minat berwirausaha dipengaruhi oleh fear of failure.

Selama proses pelaksanaan penelitian berlangsung, peneliti menyadari banyak kekurangan dan keterbatasan seperti, sulitnya mengakses wilayah yang terpilih sebagai lokasi penelitian karena keterbatasan jaringan internet dan keterbatasan jumlah sampel yang sesuai kriteria di wilayah tertentu. Selain itu, pendistribusian subjek secara kategori usia tidak sepenuhnya terwakilkan yang sesuai kriteria sehingga mayoritas subjek yang mengisi penelitian ini didominasi oleh rentang usia 18-29 tahun dan hanya sedikit subjek yang mengisi subjek dari rentang umur 30-34 tahun.

\section{Simpulan}

Hasil penelitian ini menemukan fear of failure berhubungan negatif dengan dukungan sosial pada foodpreneur, artinya bahwa semakin tinggi tinggi dukungan maka semakin tidak takut foodpreneur dalam menjalankan usaha. Salah satu aspek dukungan sosial yang membantu foodpreneur untuk tidak takut akan gagal adalah aspek dukungan sosial dari keluarga. Namun, meskipun dari data responden memiliki kategori diposisi sedang, namun banyak responden memiliki fear of failure dalam posisi rendah. Hal yang membuat ini terjadi karena subjek dalam penelitian memiliki perasaan malu jika mengalami kegagalan. Oleh sebab itu penting bagi foodpreneur mendapatkan dukungan yang lebih banyak selain dari keluarga baik itu dari teman maupun significant other agar foodpreneur dapat mengurangi fear of failure. Hasil penelitian menunjukkan bahwa diterimanya hipotesis pada penelitian ini yaitu 
Yugi Murdafasmi, Risana Rachmatan, Haiyun Nisa, Irin Riamanda terdapat hubungan yang negatif dengan nilai korelasi -0,264 dan signifikan dengan nilai $0,000(\mathrm{p}<0,05)$ antara dukungan sosial dengan fear of failure pada foodpreneur, maksudnya adalah semakin tinggi tingkat dukungan sosial individu maka akan semakin rendah fear of failure. Sebaliknya, semakin rendah dukungan sosial individu maka akan semakin tinggi fear of failure. Sumbangan efektif yang hanya sebesar 7,0\% memiliki arti bahwa dukungan sosial tidak menjadi faktor utama yang menyebabkan sedangnya tingkat fear of failure dalam penelitian ini. Namun ada faktor lain yang dapat memengaruhi fear of failure seperti faktor intensi, minat dan lebih spesifik lagi seperti faktor dukungan keluarga. 
Yugi Murdafasmi, Risana Rachmatan, Haiyun Nisa, Irin Riamanda

Daftar Pustaka

Adicondro, N \& Purnamasari, A. (2011), Efikasi Diri, Dukungan Sosial Keluarga dan Self Regulated Learning Pada Siswa Kelas VIII. Jurnal Humanitas,8(1).

Apandi, I., (2018, September 20). CPNS, Pengangguran dan Pentingnya Membangun Jiwa Wirausaha. Kompasiana. Di akses tanggal Agustus

2019.Melalui https://www.kompasiana.com/idrisapandi/5ba354 e943322f61d7110f82/cpns-pengangguran-dan-pentingnyamembangun-jiwa-wirausaha?page=all

Badan Pusat Statistik Provinsi Aceh (2018). Data angkatan kerja di aceh. Banda Aceh: BPS.

Badan Pusat Statistik Provinsi Aceh (2018). Data Pengangguran di aceh. Banda Aceh: BPS.

Badan Pusat Statistik. (2018). Definisi angkatan kerja. Indonesia: data pusat BPS.

Badan Pusat Statistik. (2018). Definisi pengangguran. Indonesia: data pusat BPS.

Baron, R, A., \& Byrne, D. (2000). Social Psychology (9 edition). USA: Allyn \& Bacon.

Boz, A., \& Ergeneli, A. (2014). Women Entrepreneur's Personality Characteristics and Parent's Parenting Style Profile in Turkey. Procedia-Social and Behavior Sciences, 109, 92-97. DOI: $10.1016 /$ j.sbspro.2013.12.425

Brannon, L., \& Feist, J. (2009). Health Psychology An Introduction To Behavior And Health. USA: Thomson Wadsworth. 
Yugi Murdafasmi, Risana Rachmatan, Haiyun Nisa, Irin Riamanda Buciyasi, N, F. (2016). Inilah Alasan Kenapa Anak Muda Cocok menjadi Foodpreneur. Diakses Desember 22, 2019, http://id.techinasia.com/alasan-anak-muda-menjadi-foodpreneur. Chua, H. S., \& Bedford, O. (2016). A Qualitative Exploration of Fear of Failure and Entrepreneurial Intent in Singapore. Journal of Career Development, 9(4), 1-16. DOI: 10.1177/0894845315599255

Chua, M., (2019, April 2). Rudiantara: Hanya 5 Startup Yang Sirvive 95 Lainnya Gagal. Diakses Maret 26, https://www.cnbcindonesia.com/fintech/20190402102200-3764239.

Ciputra. (2015). Umur perusahaan definisi dan analisa selama 4 tahun. Diakses Desember 2019, http://ciputrauceo.net/blog/2015/5/12/umur-perusahaandefinisi-dan-analisa-selama-4-tahun.

Conroy, D. E., Kaye, M. P., \& Fifer, A. M. (2007). Cognitive Links Between Fear Of Failure And Perfectionism. Journal of Rational-Emotive \& Cognitive Behavior Therapy, 25(4), 237-253. DOI: $10.1007 / \mathrm{s} 10942-007-0052-7$

Debora, Yantina., (2017, Juli 13). PNS, Profesi yang Banyak Dicari Orang. Diakses September 15, 2019, https://tirto.id/pns-profesi-yangbanyak-dicari-orang-csAB

Ekasari, A. K., (2014). Pengaruh Dukungan Orang Tua dan Kemampuan Membagun Relasi Terhadap Motivasi Berwirausaha pada Mahasiswa Fakultas Ekonomi Universitas Negeri Surabaya. Jurnal Ekonomi Pendidikan dan Kewirausahaan, 2(2), 98-106. DOI: http://dx.doi.org/10.26740/jepk.v2n2.p201-211

Elliot, A. J., \& Sheldon, K. M. (1997). Avoidance achievement motivation: A personal goals analysis. Journal of Personality and Social 
Psychology, 73(1), 171-185. https://doi.org/10.1037/00223514.73.1.171

Emerhub.id., (2019, Maret). Kenali 5 Macam Entrepreneur di Indonesia.

Di akses pada 6 Desember 2019. Melalui https://emerhub.com/idkewirausahaan/kenali-5-macamentrepreneur-di-indonesia/.

Fatir, D., (2017, 1 Juli). Jk Dorong Generasi Muda Menjadi Pengusaha. Antara News. Di akses pada Agustus 2019. Melalui https://m.antaranews.com/berita/638087/jk-dorong-generasimuda-menjadi-pengusaha.

Fitri, A. (2015). Aceh Baru Punya 57 ribu Entrepreneur. Diakses pada Septermber 2009.

Melalui https://www.google.co.id/url?sa=t\&rct=j\&q=\&esrc=s\&source=we $\mathrm{b} \& \mathrm{~cd}=\& \mathrm{cad}=\mathrm{rja} \&$ uact $=8 \& \mathrm{ved}=2$ ahUKEwit75yV8dvtAhWPfH0KHR FzCwoQFjAAegQIAhAC\&url=https\%3A\%2F\%2Faulia87.wordpres s.com\%2F2015\%2F01\%2F30\%2Faceh-baru-punya-57-ribuentrepreneur-lalu\%2F\&usg=AOvVaw3XdFzvEcglc3g3K6Mbjxyc

Green, F., (2013). Youth Entrepreneurship: A background paper for the OECD Centre for Entrepreneurship, SMEs and Local Development.

Hardiansyah, H., (2011). Ketakutan Akan Kegagalan (Fear Of Failure) Sebagai Bentuk Kepercayaan Irasional (Irrational Belief) pada Mahasiswa Senior yang Melakukan Prokrastinasi Akademik dengan Cara Menunda Pengerjaan Skripsi. Skripsi Tidak Dipublikasi. Surabaya, Universitas Airlangga.

Kew, J., Herrington, M., Litovsky Y., \& Gale, H. (2013). Generation Entrepreneur? The state of global youth entrepreneurship.

Kiswanto. A., (2017). Karakteristik Rasa Takut Gagal (Fear Of Failure) pada Young Entrepreneurial Berdasarkan Minat Karier 
Yugi Murdafasmi, Risana Rachmatan, Haiyun Nisa, Irin Riamanda

Mahasiswa. Jurnal Fokus Konseling, 3(1), 47-56. https://doi.org/10.26638/jfk.288.2099

Kuncoro, M. (2002). Metode Riset Untuk Bisnis dan Ekonomi. Jakarta: Erlangga.

Marini, C. K., \& Hamida, S. (2014). Pengaruh Self-Efficacy Lingkungan Keluarga dan Lingkungan Sekolah terhadap Minat Berwirausaha Siswa SMK Jasa Boga. Journal Pendidikan Vokasi, 4(2), 195-207. DOI: https://doi.org/10.21831/jpv.v4i2.2545

Maulida, S. R., \& Dhania, D. R. (2012). Hubungan Antara Kepercayaan Diri dan Dukungan Orang Tua dengan Motivasi Berwirausaha pada Siswa SMK. Jurnal Psikologi Undip, 11(2), 1-9. DOI: https://doi.org/10.14710/jpu.11.2.9

Muhadi, F. X., \& Saptono, L. (2005). Jiwa Kewirausahaan Siswa SMK: Suatu Survei pada 3 SMK Negeri dan 7 SMK Swasta di DIY. Widya Dharma, 16(1).

Rachman, D.A., (2018, 17 Oktober). BKN: Jumlah Pelamar CPNS 2018 di Bawah Target. Di akses pada tanggal Agustus 31, 2019. Melalui Kompas.com.https://nasional,kompas.com/read/2018/10/17/06 194671/bkn-jumlah-pelamar-cpns-2018-di-bawah-target

Safitri, A, E., Suharso, P., \& Ani, H, M. (2015). Motivasi berwirausaha mahasiswa fakultas keguruan dan ilmu pendidikan universitas jember dalam pemanfaatan waktu luang. Unej Jurnal, 1(1), 1-8

Sagar, S. S., \& Stoeber, J. (2009). Perfectionism, fear of failure, and affective responses to success and failure: The central role of fear of experiencing shame and embarrassment. Journal of sport \& exercise psychology, 31(5), 602-627. DOI: 10.1123/jsep.31.5.602

Sarafino, E. P \& Smith, T. W. (2010). Health psychology-biopsychososial interaction. The United State Of America: John Wiley \& Sons 
Yugi Murdafasmi, Risana Rachmatan, Haiyun Nisa, Irin Riamanda

Sarason, I. G., Levine, H. M., Basham, R. B., \& Sarason, B. R. (1983). Assessing social support: The Social Support Questionnaire. Journal of Personality and Social Psychology, 44(1), 127-139. https://doi.org/10.1037/0022-3514.44.1.127

Sarason, I. G., Sarason, B. R., E. N. Pierce, G. R. (1987). A brief measure of social support: Practical and theoretical implications. Journal of Social and Personal Realitionship, 4(4), 497-510. https://doi.org/10.1177/0265407587044007

Sarwoko, E. (2011). Kajian Empiris Entrepreneur Intention Mahasiswa. Jurnal Ekonomi Bisnis, 16(2), 126-135.

Septiawati, S. (2017). Pengaruh dukungan social dan kepribadian ekstraversi terhadap motivasi berwirausaha pada mahasiswa. $\begin{array}{lll}\text { Jurnal } & \text { Ecopsy, } & \text { 77-84. }\end{array}$ http://dx.doi.org/10.20527/ecopsy.v4i2.3848

Shinnar, R. S., Janssen, F., \& Giacomin, O. (2012). Entrepreneurial Perception and Intentions: The Role of Gender and Culture. Entrepreneurship Theory and Practice, 36(3), 465-493. https://doi.org/10.1111/j.1540-6520.2012.00509.x

Sholihin, B. (2019). 7 Alasan Mengapa Pengusaha Bisnis Kuliner Sering Gagal. Diakses pada pada tanggal Desember 15, 2019. Melalui Tempo.

https://www.google.com/amp/s/bisnis.tempo.co/amp1178601/7alasan-mengapa-pengusaha-bisnis-kuliner-sering-gagal.

Storey, D.J., \& Greene, F.J. (2010) Entrepreneurship and Small Businesses, Pearsons: Harlow.

Sukirno, S., (2008). Mikro Ekonomi Teori Pengantar. Jakarta: PT. Raja Grafindo Persada. 
Yugi Murdafasmi, Risana Rachmatan, Haiyun Nisa, Irin Riamanda

Susanto, A, B., Wijanarko, Himawan, Patricia, \& Martonoso, S. (2007). The Jakarta Consulting Group on Family Business. Jakarta: Jakarta Consulting Group.

Taylor, S,E., Peplau, L.A., \& Sears, D,0. (2009). Psikologi Sosial: Edisi Kedua Belas. Jakarta: Kencana Prenada Media Group.

Titik, P. (2006). Faktor Pendorong Motivasi berwirausaha. Jurnal Penelitian Ekonomi dan Bisnis, 5(1), 39-46.

Toding, W, R, B., David, L., \& Pali, C. (2015). Hubungan dukungan sosial dengan motivasi berprestasi pada mahasiswa angkatan 2013 Fakultas Kedokteran Universitas Sam Ratulangi. Jurnal e-Biomedik (eBM), 3(1), 1-7. https://doi.org/10.35790/ebm.3.1.2015.6619

Upton, P. (2012). Psikologi Perkembangan. Jakarta: Penerbit Erlangga.

Walipah, W., \& Naim, N. (2016). Faktor - Faktor Yang Mempengaruhi

Niat Berwirausaha Mahasiswa. Jurnal Ekonomi Modernisasi, 12(3), 138-144. https://doi.org/10.21067/jem.v12i3.1461

Wibawa, C, A., (2014). Hubungan Fear of Failure Dengan Minat Berwirausaha Multi Level Marketing (Mlm) Pada Mahasiswa. Skripsi. Fakultas Psikologi Universitas Sumatera Utara.

Winosa, Y., (2019, 13 Februari). Alasan 90 persen startup gagal. Di akses pada $\quad$ Maret $2619 . \quad 262$ melalui https://www.wartaekonomi.co.id/read215393.html

Zimet, D, G., Dahlem, N., \& Farley, G, K. (1988). Psychometric Characteristics of the multidimensional scale of perceived social support. Journal of personality assessment. 55(3\&4), 610-617.

Zimet, D, G., Dahlem, N., \& Farley, G, K. (1988). Psychometric Characteristics of the multidimensional scale of perceived social support. Journal of personality assessment. 52(1), 30-41. 